\title{
Chilean Antarctic krill fishery (2011-2016)
}

\author{
Patricio M. Arana ${ }^{1}$, Renzo Rolleri $^{1}$ \& Álvaro De Caso ${ }^{1 *}$ \\ ${ }^{1}$ Escuela de Ciencias del Mar, Pontificia Universidad Católica de Valparaíso \\ Valparaíso, Chile \\ *Actual address: Especialistas Pesqueros, Santiago, Chile \\ Corresponding author: Patricio M. Arana (patricio.arana@pucv.cl)
}

\begin{abstract}
Antarctic krill (Euphausia superba) is a key resource in the Antarctic region, as it is the primary food source for fish, whales, seals, flying birds, penguins and cephalopods. The high concentrations of the species and its possible uses -food for human and animal consumption and in the production of industrial, pharmaceutical and dietetic products- generates interest in the fishing industry. Its relevance motivated the implementation of administrative measures and international regulations for this fishery, which are summarized in this review. Chile is the only South American fishing country that has shown interest in participating in Antarctic krill fishery. Thus, between 1983 and 1994, the Fisheries Development Institute and some companies carried out fishing activities mainly aimed at prospecting and researching this species. However, starting in 2011, the factory trawler FV Betanzos began sustained commercial krill fishing aimed at krill meal production. This document analyzes the information collected by said vessel between 2011 and 2016, including areas of operation, fishing depth catches and CPUE obtained. Also, the main challenges faced by this fishery and the actions planned as solutions are assessed.
\end{abstract}

Keywords: Euphausia superba; krill; fishing operations; CPUE; Conservation Measures; Antarctic region

\section{INTRODUCTION}

The ocean that surrounds the Antarctic continent is well-known for its high primary productivity generated by phytoplankton (Pakhomov et al., 2002; Atkinson et al., 2008). These unicellular algae provide sustenance for krill, a species of small crustaceans that live in open waters. The most common and abundant krill species in Antarctic waters is Euphausia superba (hereafter referred to as 'krill'). The word Euphausia derives from Greek for good or true, combined with phausia for shining or light emitting, and the word "krill" was first used in this sense by Norwegian whalers who applied it to the swarming little fish (krill) which signaled whale feeding grounds (Guglielmo et al., 2015).

These great aggregations have also draw human interest in using the abundant krill as a source of protein and sub-products. Hence, this resource is exploited for the elaboration of krill pastes for human consumption, krill oil and krill meal for balanced animal feed, as well as derivative products such as omega-3 tablets and dyes (Budzinski et al., 1985; Nicol et al., 2000; Burri \& Johnsen, 2015).

The Commission for the Conservation of Antarctic Marine Living Resources (CCAMLR), an international organization forming part of the Antarctic Treaty System with headquarters in Hobart, Tasmania, Australia, administers this resource. This Commission aims towards conserving the marine flora and fauna of Antarctica, with particular attention focused on researching and monitoring krill fishery and its interaction with other species, due to the growing interest in krill exploitation. CCAMLR has established that krill fishery will not expand further without scientific data, indicating that said expansion is not competitive with natural predators of krill, including fish, whales, seals, flying birds, penguins and cephalopods. 
A total of five countries currently catch krill in the Southern Ocean (CCAMLR Secretary), being Chile the only Latin American one, with sporadic activities carried out since 1970. Thereby, from 2011 to 2016, the factory trawler FV Betanzos was used for the extraction of this resource for meal production. Since December 2017 another Chilean ship (FV Antarctic Endeavour), built especially for fishing and processing krill, has replaced it in these tasks.

The importance of this resource in the Antarctic ecosystem and the growing fishery interest motivated by its abundance encourages the need to research krill biology, behavior and status, in order to have up-to-date scientific information to define and regulate its exploitation. This document contributes to this by presenting the results of five years of commercial krill fishing, the main characteristics associated with Antarctic krill fishery regulation, and its predictable future.

\section{THE ANTARCTIC KRILL RESOURCE}

These small crustaceans are distributed around the entirety of Antarctica; however, their main distribution is located in statistical area 48 established by the Food and Agriculture Organization of the United Nations (FAO), an oceanic region to the south and east of Cape Horn in the extreme south of the American continent. The main concentrations are found south of the South American continent and in the Atlantic Ocean (Statistical Area 48 of the FAO), subdivided into Subareas 48.1 (West Antarctic Peninsula, Bransfield Strait, Gerlache Strait, South Shetland Islands and Elephant Island), 48.2 (South Orkney Islands), and 48.3 (South Georgia Island), while the remaining subareas (48.4, 48.5 and 48.6) record no relevant catches (Fig. $1)$.

Krill will cluster in enormous concentrations of millions of individuals, weighing hundreds and even thousands of tonnes, and covering great extensions. These dense swarms can be found from near the surface to several hundred meters deep (up to $600 \mathrm{~m}$ ) (Miller \& Hampton, 1989; Watkins, 2000). Krill display massive daily vertical migrations making a significant amount of biomass available as food for predators near the surface at night and in deeper waters during the day (Everson, 2000). The distribution pattern of the population can be affected by currents, bottom topography, food distribution and the presence of predators.

The distinctive characteristics of Euphausia superba are: i) eyes spherical, somewhat larger in males than in females; ii) rostrum short, triangular, and truncated, slightly shorter in males than in females; iii) distal segment of mandibular palp long and slender, seven times as long as broad; iv) first segment of antennular peduncle bearing a wide lappet with a sinuous distal margin, which is stouter, narrower, and smaller in males than in females. The second segment is bearing a dorsal lappet, which is wider and larger in females - abdominal segments without mid-dorsal spines. The sixth segment as long as high; v) proximal process of petasma without keel; terminal process curved and pointed, not cleft in two; lateral process without a secondary tooth (Antezana et al., 1976; Antezana, 1985; Guglielmo et al,, 2015).

Although marine waters host a great variety of euphausiid species, the most relevant is the Euphausia superba, which is also one of the largest, growing to a larger size (3-7 cm) and weigh (up to $2 \mathrm{~g}$ ) (Siegel, 1992; Nicol \& Endo, 1997; Arana \& Rolleri, 2012). Differences between species of the Euphausia genus are determined mainly according to the shape of the distal projection of the first antennular segment, the shape of the petasma, the presence of spines on the abdominal segments and the shape of the rostrum (Antezana et al., 1976).

The main spawning season of the species is from January to March, mostly above the continental shelf (Perry et al., 2019). A condition considered favorable for a successful spawning is the extension, temporal and spatial, of the sea ice cover that occurs during winter (Perry et al., 2019). Females lay 6,000-10,000 eggs at one time in the first $100 \mathrm{~m}$ of the water column. The $0.6 \mathrm{~mm}$ fertilized eggs move with the current into the open ocean and descend for a short period to depths of 1,000 to $3,000 \mathrm{~m}$ for their embryonic development. The egg hatches as a nauplius larva; once the individuals have molted into a metanauplius, and next to the young animal starts to move towards the surface in a migration known as "developmental ascent" (Hempel \& Hempel, 1986). Later, they go through larval stages know consecutively as calyptopis and furcilia. Krill larvae emerge from the pack ice in spring more advanced than in autumn. It is probably at this point that they begin to exhibit schooling behavior and as they develop into juveniles over their second summer this behavior becomes more pronounced (Nicol \& Endo, 1997). At 15-20 mm, the juvenile krill resembles the general aspect of the adults and has adopted the adult habits, with a preferred distribution over the continental shelves. The proportion of krill measuring less than $30 \mathrm{~mm}$ could be used to derive as a recruitment index.

As planktonic organisms, their behavior is passive, and they are dragged along by marine currents. Fach \& Klinck (2006) suggest that krill populations off South Georgia in the eastern Scotia Sea could be subject to an 


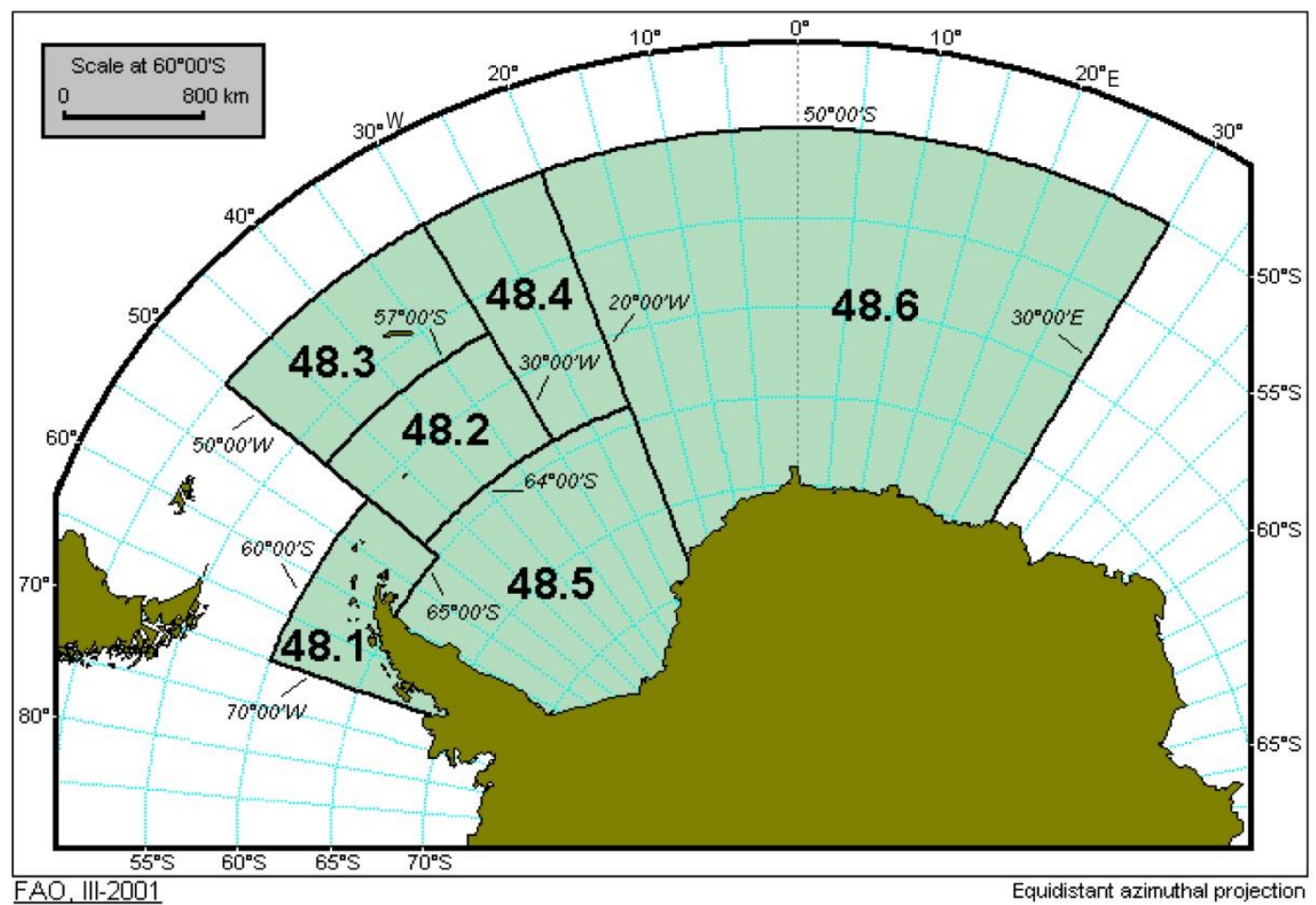

Figure 1. Major fishing statistical subareas established by FAO in the South Atlantic Ocean. From: FAO Fisheries and Aquaculture Department [online].

import of individuals from upstream regions, such as the western Antarctic Peninsula. Another possibility is that aggregations of Antarctic krill are displaced by local currents from the Bransfield Strait towards the north, between the South Sandwich Islands, thus producing a circulation (retention) effect of at least a portion of the population of this species in Subarea 48.1. Thus, the combined effects of the Coastal Current, the Bransfield Current and the northern South Shetland Current comprise a sort of clockwise circulation pattern in the region (Dotto et al., 2016; Moffat \& Meredith, 2018; Trathan et al., 2019). Oceanographic models indicate that the influence of these features would have particular relevance in krill distribution and possibly in the development of the egg and larval stages as well (Perry et al., 2019). Likewise, the models support the possibility that large aggregations of this species occur in the mentioned regions, providing krill-dependent animals extended periods with the availability of this resource for their feeding.

Juvenile growth is estimated to be slow in winter and rapid in spring-summer, displaying a lower growth rate at higher latitudes, which corresponds to cooler waters (Candy \& Kawaguchi, 2006; Constable \& Kawaguchi, 2017). Also, Antarctic krill has been observed to molt approximately every 20-30 days (Nicol \& Endo, 1997). Krill reach maturity between 40-
$50 \mathrm{~mm}$, when they are in the open ocean; females become sexually mature as age class $2+$, while males become mature as age class 3+ (Siegel \& Loeb, 1994). The average individual lifespan varies from two to seven years (Nicol \& Endo, 1999; Constable \& Kawaguchi, 2017), although they can live up to 11 years (Ikeda, 1985).

Their diet consists mainly of phytoplankton (microscopic plants in suspension such as flagellates and diatoms) and algae that live under the surface of the ice (Zhu et al., 2019). This species can withstand long periods without feeding (Nicol \& Endo, 1997; Meyer, 2012).

\section{KRILL FISHERY}

Krill fishing began with exploratory purposes in 19611962, in little relevant quantities ( $<500 \mathrm{t})$, mainly carried out by ships of the former USSR (Nicol \& Endo, 1997). The CCAMLR database holds data on krill catches starting in 1973 (CCAMLR Secretariat).

After 1977, catches increased rapidly, surpassing $100,000 \mathrm{t} \mathrm{yr}^{-1}$, although with fluctuating values between years, reaching in 1986 a maximum of 425,867 t. After 1993, catch figures show a sharp decline, maintaining values varying between 80,800 and 156,000 $\mathrm{t} \mathrm{yr}^{-1}$ until 
2012 (CCAMLR, Statistical Bulletin). As of 2010, a gradual increase has been observed in Antarctic krill catches, reaching a total of $390.135 \mathrm{t}$ in 2019 (CCAMLR, 2019), an amount that could tend to increase in the coming years.

Several countries have ventured in this fishery, with the most relevant and persistent being Chile, China, Japan, Republic of Korea, Poland, Ukraine, USSR and the Russian Federation, although its permanence over time has varied throughout time. During the period registering the largest landings (1980-1992), vessels from the USSR and Japan registered the highest catches; nevertheless, between 1987 and 1992, the USSR vessels were replaced by ships chartered by the Russian Federation, as Japan remained the most important country in krill fishing. Regarding fishing volumes, between 2000 and 2009 records show that Japan, Republic of Korea, Norway, Ukraine and Poland were the main countries operating in the fishery. A significant fact in the history of this fishery is the withdrawal in 2005 of Japanese vessels and the entry of ships from Norway, quickly positioning the latter as the leading country in the extraction of this resource, registering around $50 \%$ of the total catch obtained in Subarea 48. For the period 2019-2020 are authorized vessels from Chile (1), China (4), Republic of Korea (3), Norway (4), and Ukraine (1) (CCAMLR Secretariat).

The vessels operating in this fishery have used traditional midwater trawls (Boopendranath et al., 2010). However, the Norwegian ships introduced continuous trawl fishing, in which the gear is deployed and trawls continuously for an extended period (hours or days), while the krill is continuously pumped from the cod end to the deck of the ship (Davis et al., 2009).

Krill is mainly processed into a variety of products for direct human consumption (e.g., paste, frozen tails, sticks) given their high protein value and low-fat content, for animal feed (e.g., fish farming, poultry, products for pets), and for use as bait for sport fishing (dehydrated or frozen). The rapid decomposition of the unprocessed material results in a large portion of the krill extracted being destined in situ to the manufacture of oil and meal, the latter mostly used for animal feed, as well as the production of dyes (astaxanthin) and the elaboration of diverse dietetic (e.g., omega 3 polyunsaturated fatty acids) and pharmaceutical products (Budzinski et al., 1985; Nicol et al., 2000; Burri \& Johnsen, 2015).

\section{Biomass and total allowable catch (TAC's)}

Since the start of the exploration of krill as a resource, there has been speculation about the real magnitude of its biomass. Assessing this information is hindered by various factors, given the vastness of the area the species inhabits around Antarctica, the seasonality of its abundance, the movement of the waters that transport them and the climate. Since the 1970s, a wealth of data has been collected to help on the estimation on the species abundance. These include a series of large-scale, semi-synoptic surveys that have been used to determine the distributions of krill, including, for example, FIBEX 1981 (El-Sayed, 1994); BIOMASS-1981 (Trathan et al., 1995); SIBEX 198485 (Siegel, 1986); CCAMLR 2000 (Constable et al., 2000); Southern Ocean GLOBEC 2001-2005 (Skjoldal et al., 2013); US AMLR 2011 (Walsh, 2014); Palmer LTER (Saba et al., 2014); and others minor relevant national or international surveys. The most significant research evaluating krill biomass corresponded to the CCAMLR Krill Survey-2000. It consisted of an international effort based on hydroacoustic research that used four vessels and covered an area of approximately $2 \times 10^{6} \mathrm{~km}^{2}$; the results determined total biomass of around 60.3 million $\mathrm{t}$ in Subareas 48.1, 48.2, 48.3 and 48.4 combined (Constable et al., 2000; Trathan et al., 2001; Hewitt et al., 2002, 2004; Watkins et al., 2004; Hill et al., 2016).

Based on that research, a maximum catch limit of around 5.61 million $t$ was established per season for these subareas as a protection measure (CCAMLR, 2010). This catch limit was based on the biomass previously indicated with a survey coefficient of variation $(\mathrm{CV})$ of $12.8 \%$, and a fraction of the population referred to as $\gamma$ (gamma) estimated using the generalized yield model (GYM) of 0.093 (CCAMLR, 2017a,b; CCRVMA, 2018a). However, given this species' key role in the Antarctic ecosystem, a maximum of $620,000 \mathrm{t}$ of the total annual catch has been set as a precautionary measure (approximately 1\% of the estimated unexploited biomass), established as a trigger catch level. The maximum registered annual catch level of 390,135 t in 2019 constitutes approximately $0.62 \%$ of the estimated total krill biomass. Currently, the fishery does not exploit the total trigger level, and for this reason, is considered to be precautionary and sustainable (Hill et al., 2016). Additionally, so as to avoid concentrating the fleet operation in one area, the trigger level for E. superba catch establishes that no more than the following percentages of the maximum annual catch $(620,000 \mathrm{t})$ can be taken from the nominated Statistical Subareas: $25 \%$ from Subarea 48.1, 45\% from Subarea 48.2, 45\% from Subarea 48.3, and 15\% from Subarea 48.4 (CCAMLR, Conservation Measure 51-07, see Table 1).

In order to update the distribution and biomass of krill resource in the current fishing zones, in the austral summer of 2019, a large-scale survey was carried out 
Table 1. Summary of current CCAMLR Conservation Measures (CM) in force for the krill Euphausia superba fishery in Subareas 48.1, 48.2, 48.3, and 48.4 (CCAMLR, 2020).

\begin{tabular}{|c|c|}
\hline Topic & Measure \\
\hline Target species & Euphausia superba and any others species is bycatch. \\
\hline Season & 1 December to 30 November of the following year. \\
\hline Vessel & $\begin{array}{l}\text { All fishing vessels to operate in the Convention Area must be marked in } \\
\text { such a way that can be readily identified. }\end{array}$ \\
\hline $\begin{array}{l}\text { Vessel Monitoring } \\
\text { Sytems }\end{array}$ & $\begin{array}{l}\text { Al vessel must be equipped with a satellite-based monitoring system } \\
\text { (VMS). For krill fisheries, the system must transmit data every four hours, } \\
\text { to charge to every hour commencing } 1 \text { Decenber } 2019 \text {. }\end{array}$ \\
\hline Fishing gears & $\begin{array}{l}\text { Trawling only, with midwater trawls; conventional trawl, continuos } \\
\text { fishing system, pumping to clear codend. The use of net monitor cables on } \\
\text { vessels is prohibited. }\end{array}$ \\
\hline $\begin{array}{l}\text { Notification of intent to } \\
\text { participate in the fishery }\end{array}$ & $\begin{array}{l}\text { All Members intending to fish for krill for the coming season must notifify } \\
\text { the Commission, using the pro formas for that (21-03A and 21-03B), not } \\
\text { later than } 1 \text { June. Product types and methods for direct estimation of green } \\
\text { weight of krill caught is required. A vessel on Illegal, Unreported or } \\
\text { Unregulated (IUU) Vessel List shall not permitted to participate in krill } \\
\text { fisheries. }\end{array}$ \\
\hline Catch limit & $\begin{array}{l}\text { The total combined catch of Euphasia superba in Statistical Subareas } 48.1 \text {, } \\
48.2,48.3 \text { and } 48.4 \text { shall be limited to } 5.61 \text { million tonnes in any fishing } \\
\text { season. Nevertheless, the total combined catch in these subareas shall be } \\
\text { further limited to } 620,000 \mathrm{t} \text { in any fishing season. }\end{array}$ \\
\hline Trigger level by subarea & $\begin{array}{l}\text { The distribution of the trigger level by subarea will be: } 48.1-25 \%(155,000 \\
\mathrm{t}) ; 48.2-45 \%(279,000 \mathrm{t}) ; 48.3-45 \%(279,000 \mathrm{t}) \text { and } 48.4-15 \%(93,000 \mathrm{t}) \text {. } \\
\text { No more than } 75 \% \text { of the catch limit shall be taken within } 60 \text { nautical miles } \\
\text { of known breeding colonies of land-based krill-dependent predators. The } \\
\text { Scientific Committee shall provide advice to the Commission regarding } \\
\text { progress towards the development of the risk assessment framework, } \\
\text { feedback management and the spatial allocation of catch no later than the } \\
\text { end of the } 2020 / 7021 \text { fishing season, at which time this conservation } \\
\text { measure will expire. }\end{array}$ \\
\hline
\end{tabular}

Move-on rule

Minimisation of the incidental mortality of seabirds and marine mammals

Data

Scientific data reported by the CCAMLR

Scheme of international Scientific Observation

Exploratory fishery for krill

Environmental protection

Tariff classification
No move-on rules in this fishery.

Various measures are specified to reduce the incidental mortality of, or injury to, seabirds and marine mammals during trawl fishing. The use of marine mammals exclusion device on trawls is mandatory. The discharge of offal and discards (wholw fish or other organisms) shall be prohibited during the shooting and hauling of trawl gear. Nets shall be cleaned prior to shooting to remove items that might attract birds.

Catches shall be reported monthy. However, when the total reported catcg is greater than, or equal to, $80 \%$ of the trigger levels, catches shall be reported in accordance with the five-day catch and effort reporting.

Haul-by-haul catch, effort data and total green weight of krill caught and brought on board shall be reported. The systematic observer coverage scheme shall entail: a target coverage rate of no less than $50 \%$ of vessels during the 2018/17 and 2017/18 fishing seasons; no less than $75 \%$ of vessels during the 2018/19 and 2019/20 fishing seasons; and 100\% coverage in sunsequent fishing seasons.

Defines the general measure for the exploratory fisheries of krill in the Convention Area.

Several conservation measures to minimise possible effects on the marine environment arising from fishing-related activities in the context of mitigating incidental mortality of non-target species and protecting the marine environment. Prohibition of discharge oil, garbage, baits, any product from the processing, by-catch, etc.

Urges the contracting parties to introduce into their domestic law, an appropiate tariff classification in order to improve knowledge of the volume and trade of Antarctic krill.
Conservation Measure or Resolution

CM 51-01 (2010)

CM 10-01 (2014)

CM 10-04 (2018)

CM 21-03, Annex A (2019) CM 25-03 (2019)

CM 21-03 (2019)

CM 51-01 (2010)

CM 51-07 (2016)

CM 25-03 (2018)

CM 51-01 (2018)

CM 23-06 (2012)

CM 51-06 (2019)

CM 51-04 (2019)

CM 26-01 (2019)

Res. 27/XXVII (2016) 
in Area 48, coordinated by Norway scientists engaging international partners and CCAMLR scientific working groups (Macaulay et al., 2019). The design and sampling protocol used was similar to the ones used in the CCAMLR-2000 Survey in order to allow comparing the results obtained in this cruise with those previously obtained (Knutsen et al., 2018; Kraff, 2018a,b). The survey involved co-operative fishing vessels of the Association of Responsible Krill Fishing Companies (ARK: seven companies integrated by Chile, China, Republic of Korea, and Norway) and Ukraine, and scientific ships from Norway and the United Kingdom. The krill biomass estimate from International Large-Scale Synoptic Krill Survey in Area 48 was 62.6 million tonnes with a coefficient of variation (CV) of 13\% (CCAMLR, 2019).

\section{Conservation measures}

Since the CCAMLR came into force (1982), this organization has been particularly concerned about regulating krill fishing operations, given its importance in the Antarctic trophic web and the fact that krill is one of the primary resources exploited around the continent, using an "ecosystem approach". The essence of the "ecosystem approach" to management can be found in Article II of the Convention, which spells out the management goals in following general terms: 1 . The objective of this Convention is the conservation of Antarctic marine living resources; 2. For the purposes of this Convention, the term "conservation" includes rational use; and, 3. Any harvesting and associated activities in the area to which this Convention applies shall be conducted in accordance with the provisions of this Convention and with the following principles of conservation: a) prevention of decrease in the size of any harvested population to levels below those which ensure its stable recruitment. For this purpose its size should not be allowed to fall below a level close to that which ensures the greatest net annual increment; b) maintenance of the ecological relationships between harvested, dependent and related populations of Antarctic marine living resources and the restoration of depleted populations to the levels defined in subparagraph above; and c) prevention of changes or minimization of the risk of changes in the marine ecosystem which are not potentially reversible over two or three decades, taking into account the state of available knowledge of the direct and indirect impact of harvesting, the effect of introduction of alien species, the effects of associated activities on the marine ecosystem and the effects of environmental changes, with the aim of making possible the sustained conservation of Antarctic marine resources.
During the annual meeting of this organization (November 2019), the current conservation measures are revised and updated to then be applied for the following fishing season. These measures correspond mainly to regulating the maximum captures by subarea, mitigating the possible incidental capture of birds and mammals, protecting the environment, regulating measures to ships' operation and having mandatory scientific observers onboard the ships (see Table 1).

In parallel, CCAMLR is studying the establishment of several Marine Protected Areas (MPAs) in the Antarctic region, most of them in areas where krill is currently being fished, in order to contribute to the its protection and to avoid its extraction to compete with natural krill predators. Example of this MPAs are the two already established: the first in the southern shelf of the South Orkney Islands (CCAMLR Conservation Measures 91-03/2012) and the second in the Ross Sea (CCAMLR Conservation Measures 91-05/2016), while others are proposed in the east Antarctica, in the Weddell Sea (Domains 3 and 4) and in the Antarctic Peninsula region (Domain 1) (CCAMLR, 2019).

While the possible establishment of these MPAs is under analysis, the Association of Responsible Krill Harvesting Companies (ARK), formed by the leading companies that exploit this resource, established a voluntary agreement stating that, as of January 1, 2019, they will restrict extractive operations from October to March to a distance greater than $40 \mathrm{~km}$ off the coast in penguin breeding areas in the Antarctic Peninsula, South Shetland Islands and Gerlache Strait (ARK, 2018).

\section{CHILEAN KRILL EXPLOITATION (2011-2016)}

In virtue of the proximity of its ports to the Antarctic continent and the areas where the main concentrations of krill are found, between 1974 and 1984, the Chilean government promoted the research of this resource organizing expeditions in Antarctic waters, carried out by the Institute of Fisheries Development (IFOP) and the development of various works with the collaboration of numerous researchers and national institutions (Lillo \& Guzmán, 1982; Guzmán, 1985). The purpose of these expeditions was to research this resource and determine the possibility of exploitation and use for human consumption (Eberhard, 1982, 1983). Although these actions did not lead to the development of this fishery, they allowed for several attempts to extract this species over short periods, which were soon abandoned.

More recently, given the decrease in abundance of fish species traditionally extracted in Chilean jurisdictional waters, the fishery company Pesca Chile S.A., followed by Antarctic Sea Fisheries S.A., grew interested in developing krill fishery. Thus, from 2011 to 
2016, the FV Betanzos (72 $\mathrm{m}$ in length and 1,439 gross registered tonnage) was used to extract $E$. superba. At the same time, these expeditions allowed gathering information on the resource and on the characteristics of these fishing operations; a description of the analysis of such data is provided below.

\section{Analyzed information}

In this document, we report on the analysis of data from the vessel logbooks, which include information on the location of fishing hauls, as well as records of effort, catch, and the general characteristics of each haul (geographical position, depth (m), duration of trawl (h) and catch $(\mathrm{kg})$ ). The FV Betanzos carried out the extractive operations between 2011 and 2016 in Statistical Subareas 48.1, 48.2, and 48.3. Also, reports provided by the National Scientific Observers who worked permanently aboard the ship were used. This information was registered in Excel files provided by the CCAMLR to be filled in situ, according to its Scientific Observers Manual (CCAMLR, 2011).

The operation of the FV Betanzos in the krill fishery was authorized each year by the Chilean Undersecretariat of Fisheries of the Chilean government and by CCAMLR.

An annual summary was made detailing the number of trips, the date and days of the fishing operations, as well as the totals per year, subarea, and the total number of hauls with and without catch carried out by the vessel. Along with this, we present the depth distribution frequencies in which the trawls were carried out, by year and subarea. Maps of the catches were made per year and fishing subarea (48.1, 48.2 and 48.3) using the Surfer geostatistical software to visualize the haul's geographical location carried out during the study period.

The total Antarctic krill catches obtained in the successful hauls were added by year and by subarea. Also, to facilitate the interpretation of these results, additional box-and-whisker diagrams or boxplots are provided (Chambers et al., 1983), describing the range observed in the catches per haul and the average value, and \pm 1 standard deviation concerning the respective average value is included as a measure of dispersion. The catch per unit of effort (CPUE) calculation was established globally for the entire study period in each subarea using the relative frequency distribution using the logarithmic function of CPUE (log of catch per minute of fishing $\left(\mathrm{kg} \mathrm{min}^{-1}\right)$ ) at intervals of 0.1 (CCAMLR, 2016).

\section{Operational results}

\section{Number of trips and duration of fishing efforts}

The number of trips carried out per year varied between 3 and 5, with 2013 presenting the highest amount and 2011, 2015 and 2016 the lowest (Table 2). However, the fishing days fluctuated between 14 and 58 days, with the highest number of days by year was registered in 2012 (175 days). Later, the duration of the fishing days remained around 150 days, decreasing markedly in 2016 ( 72 days), the last year of operation of this ship (Table 2).

\section{Hauls}

The total number of hauls carried out during the 20112016 period $(n=3,257)$ reveals that the largest amount was registered in Subarea 48.1, accounting for 1,928 hauls, and far exceeding the remaining subareas; 840 in Subarea 48.3 and 489 in Subarea 48.2 (Table 3). As a global average, $96 \%$ of the hauls were successful, so a similar situation is observed when considering hauls with a yielded catch $(\mathrm{n}=3,129)$, with 1,890 hauls in Subarea 48.1, 776 hauls in Subarea 48.3, and 463 hauls in Subarea 48.2. Regarding trawls per year, the largest number was carried out in 2014 (749 total hauls, of which 738 yielded catch), and the lowest amount in 2016 (252 total hauls of which 239 yielded catch).

\section{Fishing depth}

The depth at which the fishing trawls were carried out varied according to the subarea (Fig. 2). In Subarea 48.1 , the hauls were mainly carried out between 0 and $120 \mathrm{~m}$ of depth, with an annual average varying during the different years between 31 and $66 \mathrm{~m}$. In Subarea 48.2 , the trawls were carried out between 20 and $140 \mathrm{~m}$ of depth, with annual averages between 54 and $115 \mathrm{~m}$. In Subarea 48.3 the trawls were carried out at a deeper range, mostly between 40 and $200 \mathrm{~m}$ of depth, with interannual means between 93 and $138 \mathrm{~m}$.

\section{Catch}

The amount of catch per year and subarea varied considerably throughout the investigated period (Table 2). In 2011, the total catch reached approximately 3,827 t. In the following years, it increased irregularly, with amounts that fluctuated between 7,200 and 9,600 $\mathrm{yr}^{-1}$, finally falling in 2016 to $3,700 \mathrm{t}$. The catch registered by FV Betanzos represented between 2 and $6 \%$ of total annual Antarctic krill catches in Area 48.

The conversion factor from green weight (fresh wet weight of captured krill) to fishmeal was between 7.0 and $8.0 \%$.

Regarding the catch by subarea, the most substantial amount was obtained in Subarea 48.1, contributing to a large part of the catches in 2013. The maximum amount of catch $(6,800 \mathrm{t})$ was obtained in 2014. In Subareas 48.2 and 48.3 , the volumes were relatively low, being under 2,300 t per year (Fig. 3). 
Table 2. The number of trips, fishing period, fishing days and catch performed by FV Betanzos in the krill Euphausia superba fishery (2011-2016).

\begin{tabular}{|c|c|c|c|c|c|c|}
\hline Year & Trip & Period & $\begin{array}{c}\text { Fishingn } \\
\text { days }\end{array}$ & $\begin{array}{c}\text { Total } \\
\text { (days) }\end{array}$ & $\begin{array}{c}\text { Catch per } \\
\text { trip }(\mathrm{t})\end{array}$ & $\begin{array}{l}\text { Annual } \\
\text { catch }(t)\end{array}$ \\
\hline \multirow[t]{3}{*}{2011} & 1 & Jun 25 - Aug 04 & 41 & 84 & $1,811.04$ & $3,827.15$ \\
\hline & 2 & Aug 27 - Sept 09 & 14 & & 558.00 & \\
\hline & 3 & Dec 11 - Jan 08 & 29 & & $1,458.11$ & \\
\hline \multirow[t]{4}{*}{2012} & 1 & Jan 18 - Feb 29 & 43 & 175 & $2,120.27$ & $7,275.53$ \\
\hline & 2 & Mar 12 - Apr 22 & 42 & & $1,697.39$ & \\
\hline & 3 & May 02 - June 12 & 42 & & $2,287.60$ & \\
\hline & 4 & June 22 - Aug 27 & 48 & & $3,290.54$ & \\
\hline \multirow[t]{5}{*}{2013} & 1 & Jan 08 - Jan 28 & 21 & 135 & $1,182.30$ & $7,242.32$ \\
\hline & 2 & Mar 23 - Apr 17 & 26 & & $1,601.28$ & \\
\hline & 3 & May 01 - June 09 & 40 & & $1,797.90$ & \\
\hline & 4 & June 29 - July 28 & 30 & & $2,085.12$ & \\
\hline & 5 & Aug 21 - Sept 07 & 18 & & 575.72 & \\
\hline \multirow[t]{4}{*}{2014} & 1 & Dec 29 - Feb 16 & 50 & 154 & $2,807.66$ & $9,603.67$ \\
\hline & 2 & Mar 03 - Apr 10 & 39 & & $2,350.42$ & \\
\hline & 3 & Apr 23 - June 01 & 39 & & $2,868.80$ & \\
\hline & 4 & Aug 14 - Sept 08 & 26 & & $1,576.79$ & \\
\hline \multirow[t]{3}{*}{2015} & 1 & Jan 27 - Mar 18 & 51 & 153 & $2,537.49$ & $7,277.62$ \\
\hline & 2 & Mar 31 - May 27 & 58 & & $2,507.90$ & \\
\hline & 3 & June 18 - July 31 & 44 & & $2,232.23$ & \\
\hline \multirow[t]{3}{*}{2016} & 1 & Feb 02 - Mar 01 & 29 & 72 & $1,148.55$ & $3,707.12$ \\
\hline & 2 & Mar 14 - Apr 22 & 40 & & $2,373.80$ & \\
\hline & 3 & May 12 - May 15 & 3 & & 184.77 & \\
\hline Tot & & & & & & $38,993.41$ \\
\hline
\end{tabular}

Table 3. Total hauls and hauls with catch recorded in Subareas 48.1, 48.2, and 48.3 during the 2011-2016 period by FV Betanzos in the krill Euphausia superba fishery.

\begin{tabular}{lrrrrrrr}
\hline \multirow{2}{*}{ Subarea } & \multicolumn{9}{c}{ Year } & \multirow{2}{*}{ Total } \\
\cline { 2 - 7 } & 2011 & 2012 & 2013 & 2014 & 2015 & 2016 & \\
\hline Total hauls & & & & & & & \\
48.1 & 149 & 276 & 344 & 526 & 431 & 202 & 1.928 \\
48.2 & 9 & 279 & 0 & 95 & 56 & 50 & 489 \\
48.3 & 227 & 151 & 158 & 128 & 176 & 0 & 840 \\
\hline Total & 385 & 706 & 502 & 749 & 663 & 252 & 3.257 \\
\hline Hauls with catch & & & & & & & \\
48.1 & 135 & 269 & 339 & 525 & 424 & 198 & 1.890 \\
48.2 & 3 & 271 & 0 & 92 & 56 & 41 & 463 \\
48.3 & 186 & 151 & 142 & 121 & 176 & 0 & 776 \\
\hline Total & 324 & 691 & 481 & 738 & 656 & 239 & 3.129 \\
\hline
\end{tabular}

\section{Catch per unit of effort (CPUE)}

In terms of catch per haul, Subarea 48.1 registered averages showing gradual growth until 2013 , when it reached an average close to $15 \mathrm{t} \mathrm{haul}^{-1}$, which then decreased between 2014 and 2015, and increased again in 2016 to $16.11 \mathrm{t} \mathrm{haul}^{-1}$, corresponding to the highest record of the period (Fig. 4). In Subarea 48.2, an irregular behavior was observed, with a steadily increase from 2011 to 2014, with an average of $12 \mathrm{t}$ haul $^{-1}$ in the last, to subsequently decline in 2015 and another increase in 2016. Subarea 48.3, despite achieving the highest average catch volumes in 2012 $\left(21.79 \mathrm{t} \mathrm{haul}^{-1}\right)$, in addition to being the subarea with the highest average extraction values, experienced a constant decrease in said amount from 2013, with an average of $12.63 \mathrm{t} \mathrm{haul}^{-1}$ in 2015 .

When analyzing the catch per unit of effort, transformed to $\log$ CPUE min $^{-1}$, a unimodal distribution 


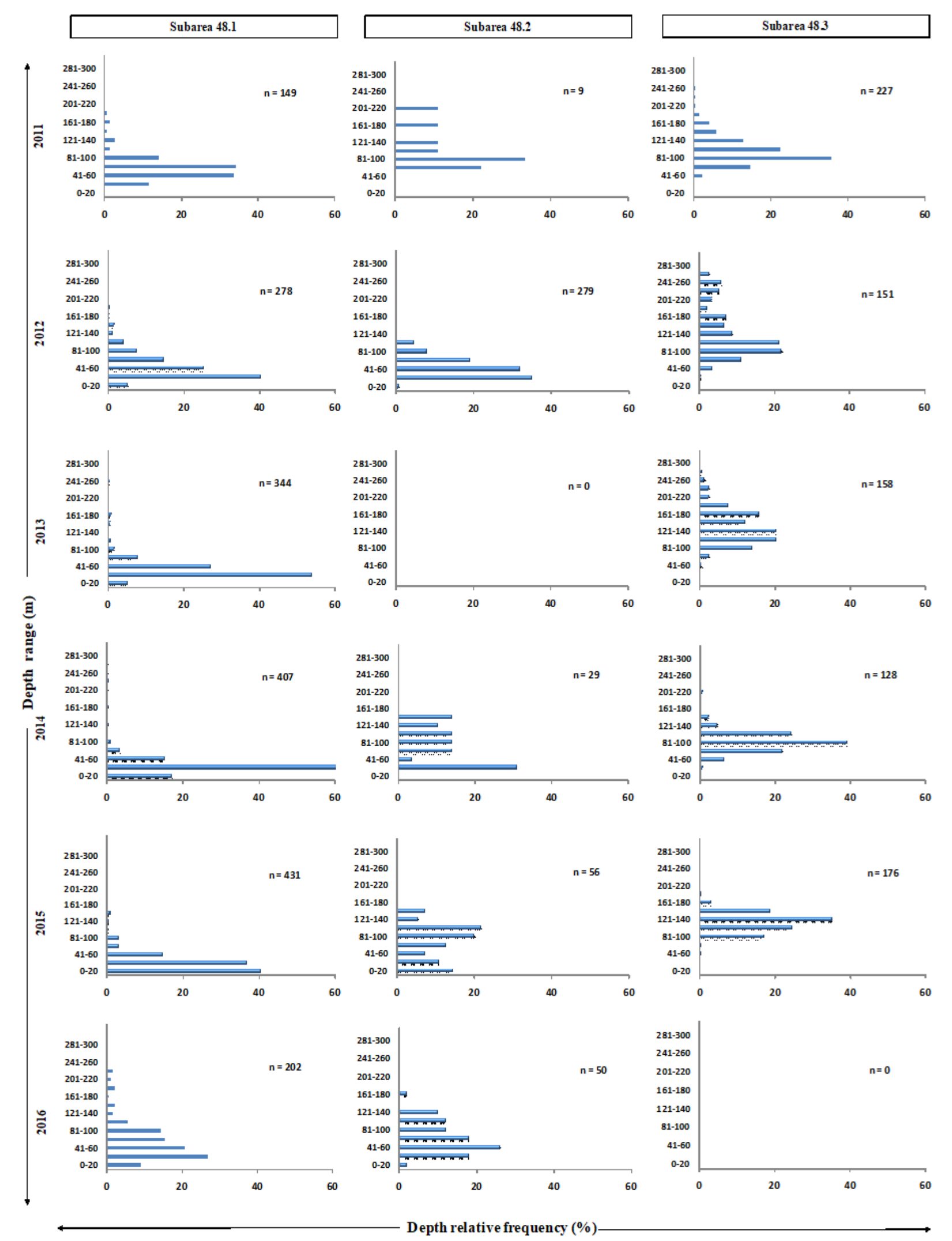

Figure 2. Depth frequency distribution for krill Euphausia superba fishery performed by FV Betanzos in subareas 48.1, 48.2, and 48.3. 


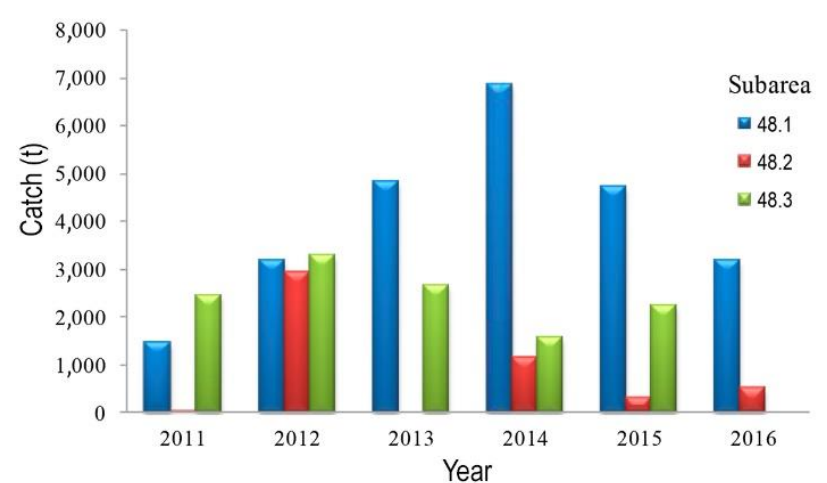

Figure 3. Annual krill Euphausia superba catch between 2011 and 2016 by FV Betanzos in subareas 48.1, 48.2 and 48.3 .

is observed in the different fishing subareas, with the mode around $\log 2 \mathrm{~kg} \mathrm{~min}^{-1}$. The range observed in Subarea 48.1 shows an approximately symmetric distribution with extreme values of 0.5 to $3.0 \mathrm{~kg} \mathrm{~min}^{-1}$ $\left(\overline{\mathrm{X}}=1.79 \pm 0.35 \mathrm{~kg} \mathrm{~min}^{-1}\right)$ while in Subareas 48.2 and 48.3 these distributions present greater dispersion, with mean values of $1.78 \pm 0.39$ and $1.95 \pm 0.41 \mathrm{~kg} \mathrm{~min}^{-1}$, respectively (Fig. 5). In the case of the first subarea, it is more likely to obtain lower than the average high catch values, while in Subarea 48.3, the probability is shared in obtaining higher or lower values of log CPUE per minute.

\section{Hauls distribution per subarea}

Within each subarea, the distribution of the hauls varied during the analyzed period (Figs. 6-8). In Subarea 48.1, the hauls carried out were mainly located in the Bransfield Strait in 2011; in the following years, fishing operations north of the South Shetland Islands were incorporated, and, in 2015, operations were extended to the north-west of Elephant Island, albeit in smaller numbers (Fig. 6).

In general, in Subarea 48.2, a significant number of hauls was carried, although in 2013 there was no fishing operations. For the most part of this subarea, the operations took place in the northwest of the South Orkney Islands, with a reduced number of hauls to the southwest of these islands in 2016 (Fig. 7).

In Subarea 48.3, the fishing activities were only carried out between 2011 and 2015, focused mainly to the northeast of South Georgia Island (Fig. 8). In the northwest area, the number of hauls gradually decreased, with no activity at all in 2015 .

\section{GENERAL COMMENTS}

Because of the considerable biomass that this species presents and the proximity of the fishing areas to Chi-
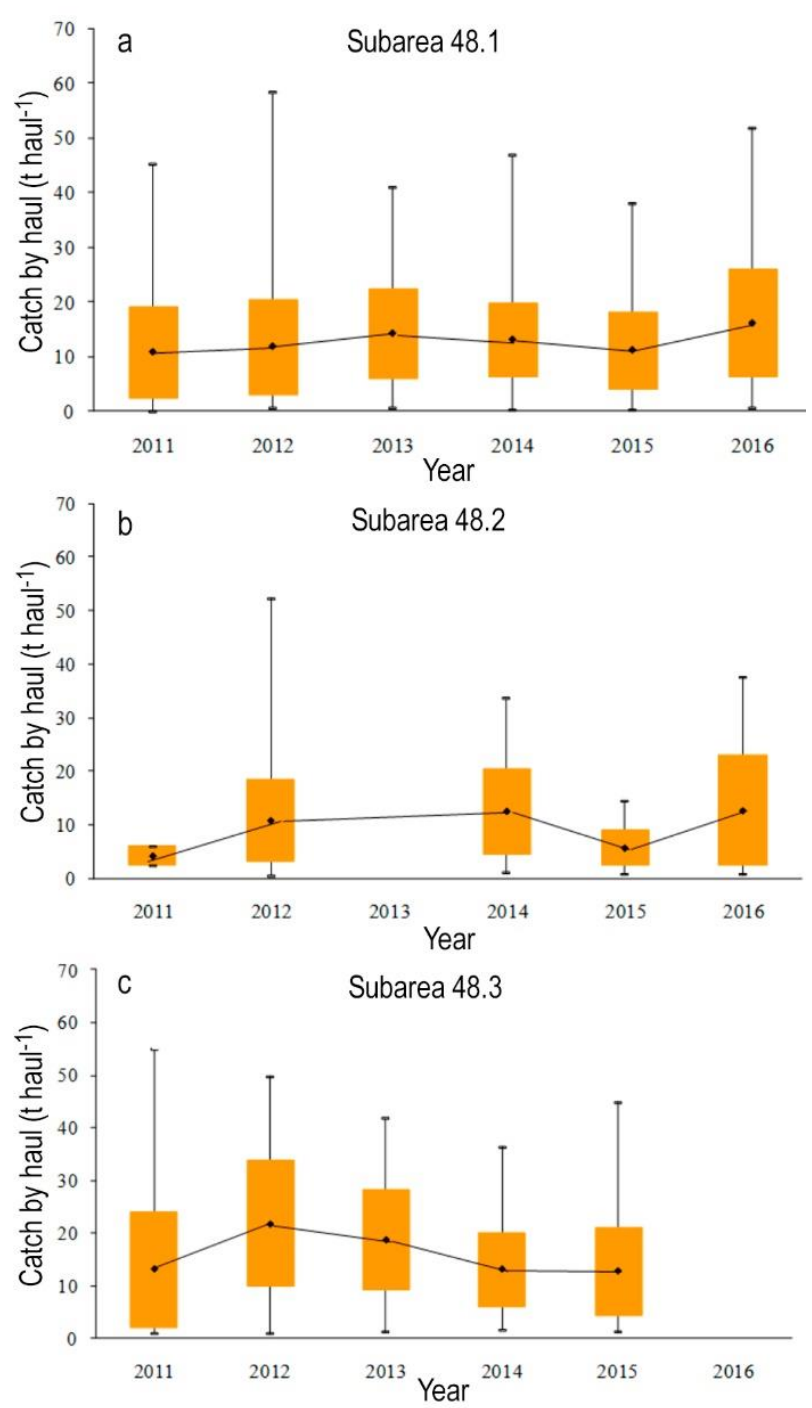

Figure 4. Annual krill Euphausia superba catch by haul (t haul $^{-1}$ ) between 2011 and 2016 carried out by FV Betanzos. a) Subarea 48.1, b) Subarea 48.2, and c) Subarea 48.3.

lean ports, this species has been considered as a potential resource since the 70s, as it could diversify the country's fishing activity and become an operationally and economically viable activity. Although there is interest in krill fishery from Chile since the 1970, some factors delayed to start as such activity. Among these factors, we can cite the availability of vessels with the necessary characteristics to operate in Antarctic waters, the rapid decomposition of the raw material and uncertainty regarding the use and sale of the production. All these factors implied that Chilean participation in the krill fishery represented a complex, risky and expensive endeavor. As of 2010, relying on larger factory vessels with improved technology, coupled with the decrease in the abundance of some fish species in the southern-austral region of Chile, this 


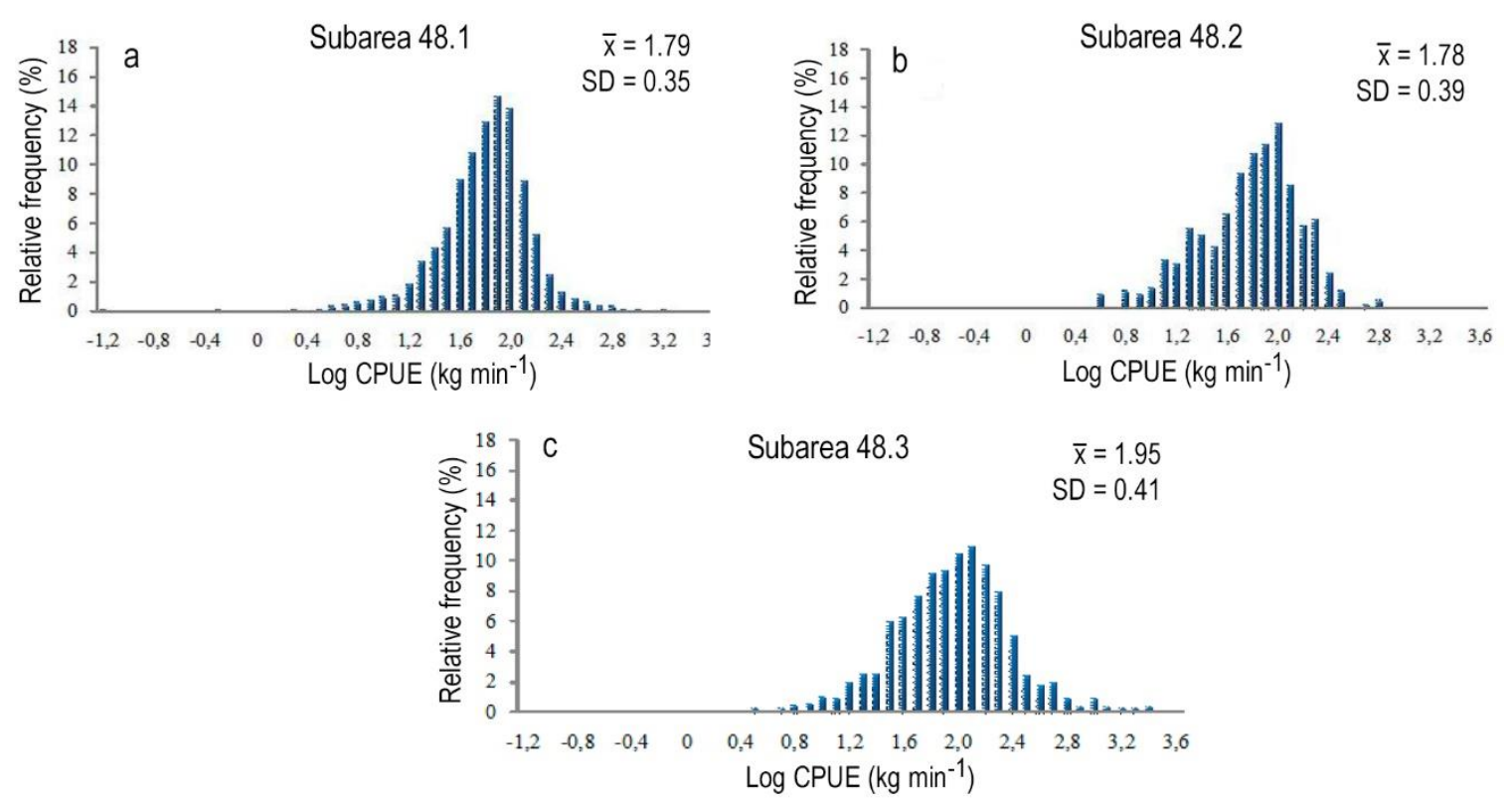

Figure 5. $\log$ CPUE $\left(\mathrm{kg} \mathrm{min}^{-1}\right)$ relative frequency distribution for krill Euphausia superba carried out by FV Betanzos during the 2011-2016 period. a) Subarea 48.1, b) Subarea 48.2, and c) Subarea 48.3.

risk was finally assumed by two Chilean companies that then promoted the development of this activity positioning Chile as the only Latin American country to participate in this fishery. The six years (2011-2016) of Chilean krill fishery data analyzed demonstrate that successful and economically viable exploitation of this resource is feasible by Chile. Considering the increasing in the demand of krill in recent years due its different uses, the investment of this country in the described activity might be profitable.

The results obtained by data on krill fishery from the FV Betanzos allowed defining the operation of the ship in the different subareas used by CCAMLR to manage the activity. During the period analyzed, the operation of the ship was recorded in certain defined areas, such as the Bransfield Strait and north of the South Shetland Islands (Subarea 48.1), northwest of the South Orkney Islands (Subarea 48.2) and northeast of South Georgia Island (Subarea 48.3) (Figs. 6-8). The persistence in the use of these areas throughout the studied year's evidence that they represent habitual Antarctic krill concentration areas where CPUE values are satisfactory to fish this resource.

The results show the variability in the yields obtained per haul, although this is not a matter of concern as the successful hauls exceeded $96 \%$. Also, it is evident that the most recurrent depths for the fishing of this species ranged between 20 and $120 \mathrm{~m}$ in Subareas 48.1 and 48.2, while in Subarea 48.3 the concentrations of E. superba were found in deeper waters, trawling as far as $280 \mathrm{~m}$ in depth (Fig. 2).
Antarctic krill possibly represents one of the most studied species, with more than 1,000 articles available regarding different aspects of it. In recent decades various multi-disciplinary studies have been performed, using technological developments and new modeling approaches. However, many details remain unknown; the views on these topics have not changed too much (Meyer, 2017). The complexity of the study associated with this resource and its fishery implies, at the very least, considering five fundamental aspects: a) the marine ecosystem as a whole, including its requirement by natural predators, b) the climateinduced variability in its biomass, c) the exact determination of the krill catch (green weight) by fleets belonging to different countries, d) the available scientific knowledge, and e) the human intervention in the Antarctic.

CCAMLR from 1973 has compiled information provided by vessels regarding their fishing operations, including the location of catches, the quantities extracted and the characteristics of the hauls and the fishing gear used. Also, the scientific observation system implemented by this Commission requires certain personnel embarked on a mandatory basis (national or international) who must collect information permanently aboard the vessels, including the collection of biological records based on samples obtained from krill catches, which are mainly directed to register frequency distributions of lengths, sex, and the presence of by-catch (species other than krill). These tasks can be helpful in providing information for 

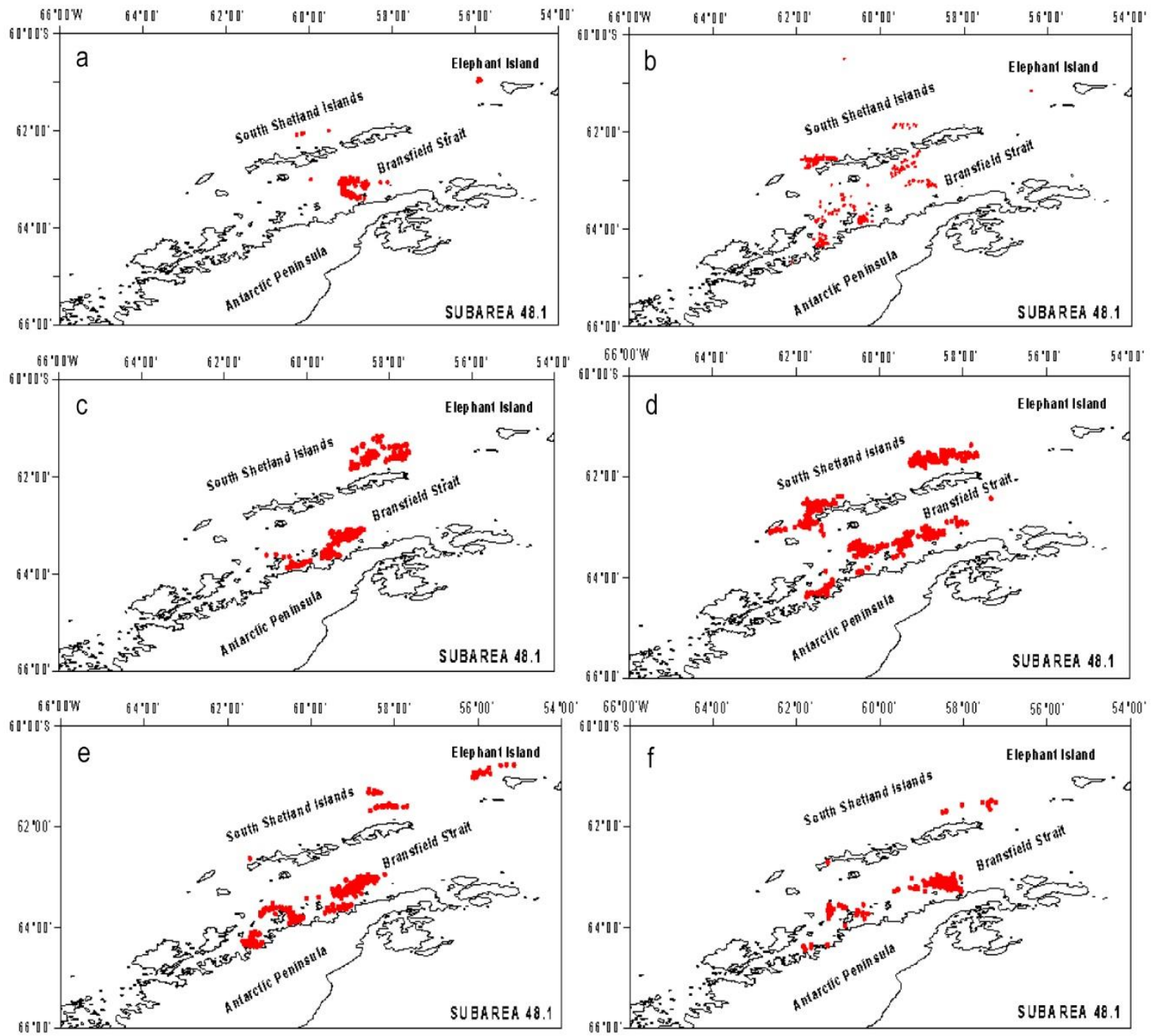

Figure 6. Geographic distribution of krill Euphausia superba fishing hauls carried out in Subarea 48.1. a) 2011, b) 2012, c) 2013 , d) 2014, e) 2015, and f) 2016.

the investigation of possible interactions occurring between fishing operations and marine birds or mammals that are krill-dependent species.

In recent years, scientists and non-governmental organizations have become very concerned that the distribution of fishing efforts has tended to concentrate on some specific regions of the Bransfield Strait, where a large number of Antarctic species that feed on krill coexist. Several factors have contributed to the current concentration of fishing efforts in the same specific areas in this strait. Such factors include regulatory dispositions (e.g., national or international regulations, licensing fees at South Georgia), environmental (e.g., changing sea-ice conditions, weather conditions), economic (e.g., subsidies, operational vessel costs, costs of searching and processing capacity), fleet dynamics (e.g., Olympic fishing, voluntary coastal closures adopted by ARK, vessel cooperation, the experience of the skipper), and available sites for protection during adverse weather conditions.

For these reasons, the scientific community must focus on determining the real status of this resource and adopt conservation measures compatible with the krill exploitation, avoiding any potential impact on the remaining species that make up the Antarctic ecosystem, especially in those areas where fishing efforts have become concentrated. Some environmental organizations and NGOs are concerned about the development of this fishery and the impact that extraction could have on the communities that feed on this species. However, according to numerous specialists, there is no evidence of a decline in krill density 


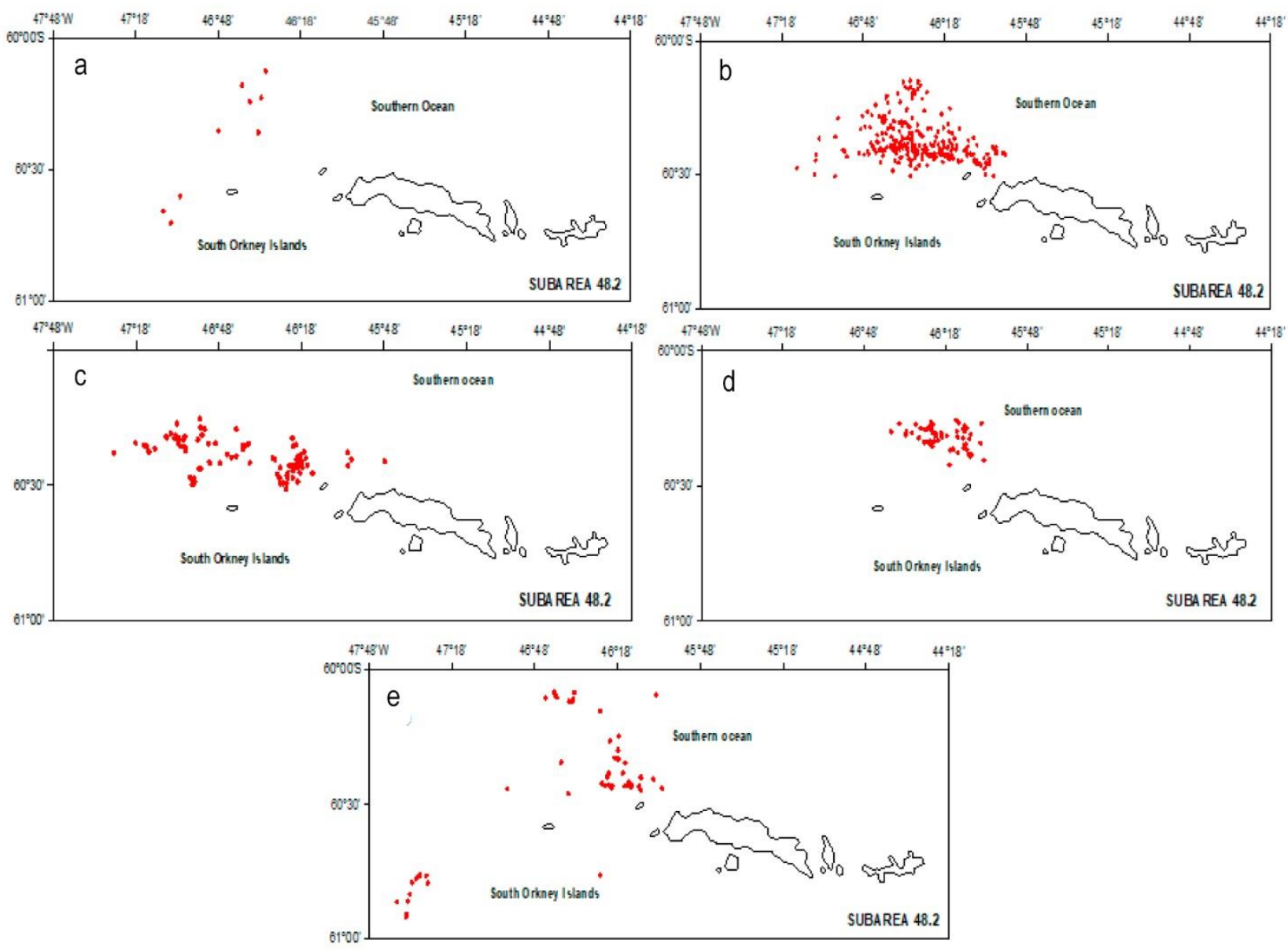

Figure 7. Geographic distribution of krill Euphausia superba fishing hauls carried out in Subarea 48.2. a) 2011, b) 2012, c) 2014 , d) 2015 , and e) 2016 .

over the last 40 years. Krill density in the SW Atlantic in the said period has fluctuated, but there is no overall decreasing trend (Hill, 2016; Cox et al., 2017, 2018). However, other evidence also exists showing a latetwentieth-century decline in Antarctic krill density (Loeb et al., 1997; Atkinson et al., 2004, 2014, 2019; Watters et al., 2013; Hill et al., 2019a). Nevertheless, it is essential to recognize that estimates of krill stock status based on currently available data will carry substantial uncertainties, and therefore require substantial precaution (Hill et al., 2019b).

The results of the International Large-Scale Synoptic Krill Survey in Area 48, led by Norway, are expected to contribute towards developing integrated methods and estimates of E. superba biomass and distribution in Statistical Area 48 and at a subarea scale (e.g., Bransfield and Gerlache Straits). Also, a regular synoptic assessment of Antarctic krill every five to ten years would help monitor any changes that occur in the population of this species, as well as in the different species that consume it and, in the environment (e.g., global warming, changing climate), which would allow time to adapt management measures.

A precautionary and ecosystem approach to fisheries management has been adopted by CCAMLR (Table 1). According to current knowledge regarding Antarctic krill, the conservation measures implemented are considered adequate for the protection of this resource. However, due to the tendency of krill to predictably aggregate in specific locations, the krill fishery and krill predators may overlap in space and time, increasing the risk of severe impacts on some predators. Consequently, CCAMLR has recognized that additional mechanisms are required to mitigate the risk of interactions, leading to a risk-based approach to distributing the krill trigger catch limit in subareas 48.1, 48.2 and 48.3 (Constable, 2016; Kelly et al., 2017).

Another management option for the Antarctic krill fishery aimed at establishing the most convenient distribution of the trigger level in the different subareas 


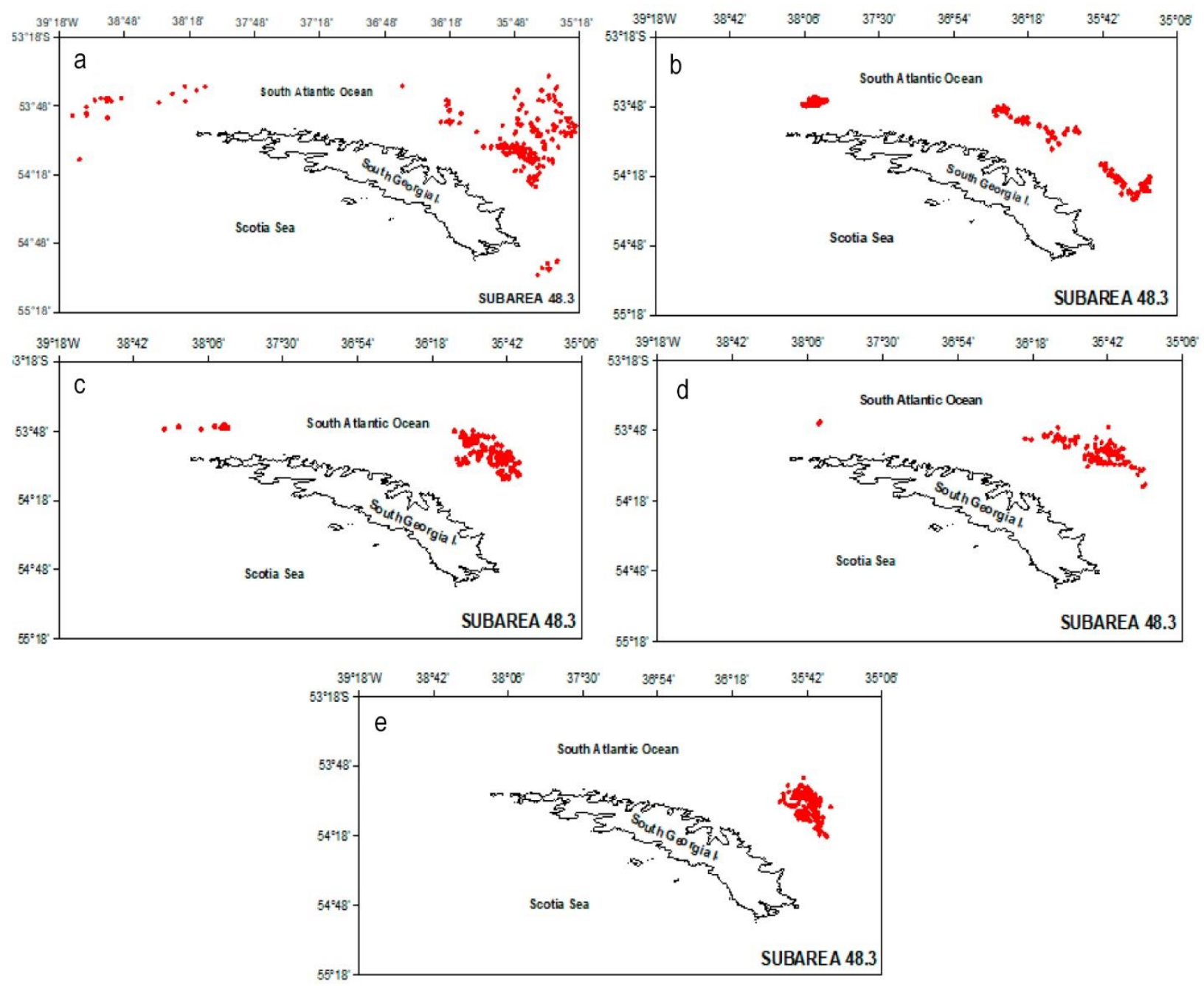

Figure 8. Geographic distribution of krill Euphausia superba fishing hauls carried out in Subarea 48.3. a) 2011, b) 2012, c) 2013 , d) 2014 , and e) 2015 .

is called Feedback Management (FBM), which considers the use of the following information sources for its implementation: a) basic quantitative knowledge of the relationship between krill and its predators; $b$ ) historic information about spatial and temporal krill catch distribution patterns; c) intermittent data collection quantifying predator colony size and food requirement including routine data collection from the Ecosystem Monitoring Program (CEMP) sites; and d) continuous flow of acoustic data from the fleet to be used to assess density distribution and abundance of krill in hotspots (Constable, 1992; Watters et al., 2016; Kraft et al., 2018b). FBM has been considered as an alternative approach for decades, but still lacks a plan that can be implemented in realistic cost and effort levels (CCAMLR, 2017a). The Commission shall seek to update or replace the conservation measure CM 5107 , which established the present distribution percen- tage of the trigger levels by subarea, in progressing feedback management, not later than the end of the 2020/21 fishing season, at which time this conservation measure will expire if an agreement has not been reached. Said impending end-date constitutes an enormous pressure for the scientific world, as it must propose a solution to this delayed commitment within the next two years.

In parallel, the proposal submitted by the Governments of Argentina and Chile to develop several Marine Protected Areas (MPAs) to conserve marine biodiversity in the CCAMLR Convention Area (CCAMLR, 2018b; Delegations of Argentina and Chile, 2018) is under study. The MPAs suggested by both countries in Domain 1 of the Antarctic region (D1MPA) would have an extension of approximately $466,000 \mathrm{~km}^{2}$, comprising three different management zones: General Protection Zone (GPZ) in which all 
types of Antarctic krill fishing would be prohibited; Krill Fishery Research Zone (KFRZ), which would allow fishing under the general rules established by CCAMLR; and a Special Fishery Management Zone (SFMZ), in which it would be possible to fish under research conditions. These incorporate the conservation of different objectives, the need for a better understanding of the krill fishery activity, and the current fishery management strategy (CCAMLR, 2018b). However, this proposal has not achieved the expected progress, and its discussion possibly will be postponed in the coming years.

On the other hand, the Marine Stewardship Council (MSC) standard, to which vessels participating in the exploitation of this species are being subjected, requires that fisheries do not cause significant and irreversible harm to the ecosystems in which they operate. Currently, only two fishing companies are certified to operate in the Antarctic krill fishery: Aker Biomarine (Noruega) and Deris S.A.-Pesca Chile (Chile).

The entry of one new krill fishing vessels from China (FV Fu Yuan Yu) is proposed for the 2019-2020 period. Incorporating technological advances for detecting krill concentrations, e.g., gliders and sailbuoys, which would increase the efficiency of searching for fishing grounds. It is thus expected that $E$. superba catches will increase in the next few years, although it will be difficult to quickly reach the maximum of $620,000 \mathrm{t}$ of the total annual catch has been set as a precautionary measure by the CCAMLR. However, the current management approach is based on generalization at a large scale and does not include the details necessary for management at finer scales (Thathan et al., 2019).

Finally, advancing research into the biological cycle of E. superba and into the studies that determine the effectiveness of the current conservation measures is urgent; or into defining those measures necessary to achieve an adequate balance between fishing activities and the feeding requirements of the animals that inhabit this unique Antarctic ecosystem. Also, regular acoustic surveys at different times of the year will increase understanding surrounding the seasonal krill dynamics. All this represents a significant challenge to develop a strategy to better fund and share the burden for research needed and to achieve in the shortest time possible the harmonization between the various strategies under study, such as risk assessment, FBM and MPAs. However, the level of precaution intended by CCAMLR Conservation Measure 51-07 should be retained while such investigations and solutions are agreed upon and implemented.

\section{ACKNOWLEDGMENTS}

The authors thank to Pesca Chile S.A. and Antarctic Sea Fisheries S.A executives for facilitating access to the records used in this document. Likewise, we value the work of the Scientific Observers who carried out their silent work aboard the ships. We recognize and appreciate the improvements obtained to this manuscript thanks to suggestions and comments from the anonymous reviewers and by the corresponding editor.

\section{REFERENCES}

Antezana, T. 1985. Euphausiids. In: Fisher, W. \& Hureau, J. (Eds.). FAO Species identification sheet for fisheries purpose. Southern Ocean. CCAMLR Convention Area Fishing Areas 48, 58, 88. Vol. 1: 71-87.

Antezana, T., Aguirre, N. \& Bustamante, R. 1976. Clave ilustrada y distribución latitudinal de los eufáusidos del Océano Antártico (Crustacea, Zooplancton). Serie Científica, Instituto Antártico Chileno, 4(1): 53-68.

Arana, P.M. \& Rolleri, R. 2012. Recursos pesqueros. In: Recursos pesqueros del mar de Chile. Arana, P.M. (Ed.). Ediciones Universitarias de Valparaíso, Valparaíso, pp. 101-286.

Association of Responsible Krill Harvesting Companies (ARK). 2018. ARK Report to SC-CAMLR-XXXVII. SC-CAMLR-XXXVII/BG/30: $14 \mathrm{pp}$.

Atkinson, A., Siegel, V., Pakhomov, E.A., \& Rothery, P. 2004. Long-term decline in krill stock and increase in salps within the Southern Ocean. Nature, 432: 100103.

Atkinson, A., Hill, S.L., Barange, M., Pakhomov, E.A., Raubenheimer, D., Schmidt, K., Simpson, S.J. \& Reiss, C. 2014. Sardine cycles, krill declines, and locust plagues: revisiting 'wasp-waist' food webs. Trends in Ecology \& Evolution, 29: 309-316.

Atkinson, A., Hill, S.L., Pakhomov, E.A., Siegel, V., Reiss, C.S., Loeb, V., Steinberg, D.K., Schmidt, K., Tarling, G.A., Gerrish, L. \& Sailley, S.F. 2019. Krill (Euphausia superba) distribution contracts southward during rapid regional warming. Nature Climate Change, 9: 142-147.

Atkinson, A., Siegel, V., Pakhomov, E.A., Rothery, P., Loeb, V., Ross, R.M., Quetin, L.B., Schmidt, K., Fretwell, P., Murphy, E.J., et al. 2008. Oceanic circumpolar habitats of Antarctic krill. Marine Ecology Progress Series, 362: 1-23. doi: 10.3354/ meps07498

Boopendranath, M.R., Nair, M.K.R. \& Anrose, A. 2010. Harvesting of Antarctic krill. Symposium on Indian Ocean Marine Living Resources (IndoMLR), 2-3 December 2010, Cochin, 11 pp. 
Budzinski, E., Bykowski, P. \& Dutkiewicz, D. 1985. Possibilities of processing and marketing of products made from Antarctic krill. FAO Fisheries Technical Paper, 268: 46 pp.

Burri, L. \& Johnsen, L. 2015. Krill products: an overview of animal studies. Nutrients, 7: 3300-3321. doi: 10.3390/nu7053300

Candy, S.G. \& Kawaguchi, S. 2006. Modelling growth of Antarctic krill. II. Novel approach to describing the growth trajectory. Marine Ecology Progress Series, 306: 17-30.

Chambers, J.M., Cleveland, W.S., Kleiner, B. \& Tukey, P.A. 1983. Graphical methods for data analysis. Duxbury Press, Boston.

Commission for the Conservation of Antarctic Marine Living Resources (CCAMLR). 2010. Report of the fifth meeting of subgroup on acoustic survey and analysis methods. In: Report of the Twenty-ninth Meeting of the Scientific Committee, Annex 4, CCAMLR, Hobart, pp. 115-244.

Commission for the Conservation of Antarctic Marine Living Resources (CCAMLR). 2011. Scientific Observers Manual (Observation guidelines and reference materials). CCAMLR, Hobart, $71 \mathrm{pp}$.

Commission for the Conservation of Antarctic Marine Living Resources (CCAMLR). 2016. An initial examination of using CPUE as a fishery performance index for the krill fishery. CCAMLR Secretary, $27 \mathrm{pp}$.

Commission for the Conservation of Antarctic Marine Living Resources (CCAMLR). 2017a. An approach to feedback management (FBM) of the krill fishery based on routine acoustic data collection and intermittent land-based predator studies (Delegations of Norway, China, and Chile). SC-CAMLR-XXXVI/BG/20: 10 pp.

Commission for the Conservation of Antarctic Marine Living Resources (CCAMLR). 2017b. Krill fishery report 2017. CCAMLR Secretary, $34 \mathrm{pp}$.

Commission for the Conservation of Antarctic Marine Living Resources (CCAMLR). 2018a. Krill fishery report 2018. CCAMLR Secretary, $31 \mathrm{pp}$.

Commission for the Conservation of Antarctic Marine Living Resources (CCAMLR). 2018b. Proposal on a conservation measure establishing a marine protected area in the Domain 1 (western Antarctic Peninsula and South Scotia Arc) (Delegations of Argentina and Chile). CCAMLR-XXXVII/31: 27 pp.

Commission for the Conservation of Antarctic Marine Living Resources (CCAMLR). 2019. Report of the thirty-eighth meeting of the Commission (Hobart, Australia, 21 October to 1 November 2019). CCAMLR, Hobart, 107 pp.

Commission for the Conservation of Antarctic Marine Living Resources (CCAMLR). 2020. Conservation
Measures 2019-2020. CCAMLR, Hobart. [https:// www.ccamlr.org/es/conservation-and-management/ conservation-measures]. Reviewed: 15 December 2019.

Constable, A. 1992. CCAMLR ecosystem monitoring and a feedback management procedure for krill. CCAMLR, WG-KRILL/CEMP-92/4: 613-626.

Constable, A., De la Mare, W., Agnew, D., Everson, I. \& Miller, D. 2000. Managing fisheries to conserve the Antarctic marine ecosystem: practical implementation of the Convention on the Conservation of Antarctic Marine Living Resources (CCAMLR). ICES Journal of Marine Science, 57: 778-791.

Constable, A. (compiler). 2016. Scientific contribution to the 2016 review of Conservation Measure 51-07: Part 1 - rationale, method, and data for a risk assessment framework for distributing the krill trigger level. CCAMLR WG-FSA-16/47 Rev. 1: $41 \mathrm{pp}$.

Constable, A.J. \& Kawaguchi, S. 2017. Modelling growth and reproduction of Antarctic krill, Euphausia superba, based on temperature, food, and resource allocation amongst life history functions. ICES Journal of Marine Science, 75(2): 738-750.

Cox, M.J., Candy, S., De la Mare, W.K., Nicol, S., Kawaguchi, S. \& Gales, N. 2018. No evidence for a decline in the density of Antarctic krill Euphausia superba Dana, 1850, in the Southwest Atlantic sector between 1976 and 2016. Journal of Crustacean Biology, 38: 656-661.

Cox, M.J., De la Mare, W.K., Nicol, S., Candy, S., Kawaguchi, S. \& Gales, N. 2017. Is there robust evidence for a major decline in krill in the south west Atlantic? 3erd. International Symposium on Krill, St Andrews, Scotland, 12 to 16 June 2017.

Davis, M., Clark, J.M. \& Peatman, T. 2009. A descriptive review of the trawl systems used in the Antarctic krill fishery. CCAMLR, TASO-09/5: 14 pp.

Delegations of Argentina and Chile. 2018. Updated background paper (2018) for the Proposal for the Establishment of a Marine Protected Area in the Western Antarctic Peninsula- South Scotia Arc (Domain 1) Part A: Domain 1 MPA Model. SCCAMLR-XXXVII/BG/07: 18 pp.

Dotto, T.S., Kerr, R., Mata, M.M. \& Garcia, C.A.E. 2016. Multidecadal freshening and lightening in the deep waters of the Bransfield Strait, Antarctica. Journal of Geophysical Research, Oceans, 121; 16 pp. doi: 10.1002/2015JC011228

Eberhard, P. 1982. Estado actual de la investigación y perspectivas de explotación del krill en la Antártica. INACH Boletín Antártico Chileno, 2(1): 32-35.

Eberhard, P. 1983. Estado actual del conocimiento y explotación del krill antártico. In: Arana, P. (Ed.). Análisis de Pesquerías Chilenas. Escuela de Ciencias del Mar, PUCV, Valparaíso, pp. 253-262. 
El-Sayed, S. 1994. History, organization, and accomplishments of the BIOMASS programme. In: Southern Ocean ecology: The BIOMASS perspective. Cambridge University Press, Cambridge, pp. 1-8.

Everson, I. 2000. Krill, biology, ecology, and fisheries. Fish and Aquatic Resources Series, 6. Blackwell Science, New Jersey.

Fach, B.A. \& Klinck, J.M. 2006. Transport of Antarctic krill (Euphausia superba) across the Scotia Sea. Part I: circulation and particle tracking simulations. DeepSea Research I, 53: 987-1010.

Guglielmo, L., Granata, A. \& Guglielmo, R. 2015. Order Euphausiacea. Revista IDE@ - SEA, 86B: 1-20.

Guzmán, O. 1985. Perspectivas de explotación del krill. Corporación de Fomento de la Producción and Instituto de Fomento Pesquero. Seminario Chile y la pesquería de krill, 108 pp.

Hempel, I. \& Hempel, G. 1986. Field observations on the developmental ascent of larval Euphausia superba (Crustacea). Polar Biology, 6(2): 121-126.

Hewitt, R.P., Watkins, J.L., Naganobu, M., Tshernyshkov, P., Brierley, A.S., Demer, S.A., et al. 2002. Setting a precautionary catch limit for Antarctic krill. Oceanography, 15(3): 26-33.

Hewitt, R.P., Watkins, J.L., Naganobu, M., Suhin, V., P., Brierley, A.S., Demer, D.A., et al. 2004. Biomass of Antarctic krill in the Scotia Sea in January/February 2000 and its use in revising an estimate of precautionary yield. Deep-Sea Research II, 51: 12151236.

Hill, S.L., Atkinson, A., Darby, C., Fielding, S., Krafft, B.A., Godø, O.R., Skaret, G., Trathan, P.N. \& Watkins, J.L. 2016. Is current management of the Antarctic krill fishery in the Atlantic sector of the Southern Ocean precautionary? CCAMLR Science, 23: $31-51$.

Hill, S.L., Atkinson, A., Pakhomov, E.A. \& Siegel, V. 2019a. Evidence for a decline in the population density of Antarctic krill Euphausia superba Dana, 1850 still stands. A comment on Cox et al. Journal of Crustacean Biology, 39(3): 316-322.

Hill, S., Hinke, J., Ratcliffe, N., Trathan, P. \& Watters, G. 2019b. Advances are urgently needed in providing regular estimates of krill stock status based on the available data. CCAAMLR, WG-EMM-2019/28: 8 pp.

Ikeda, T. 1985. Life history of Antarctic krill Euphausia superba: a new look from an experimental approach. Bulletin of Marine Science, 37: 599-608.

Kelly, N., Cox, M., Emmerson, L., Kawaguchi, S., Raymond, B., Southwell, C. \& Welsford, D. 2017. Towards an ecological risk assessment of krill fishing in East Antarctica (CCAMLR Divisions 58.4.1 and 58.4.2). CCAMLR WG-EMM-17/20: 33 pp.
Knutsen, T., Krafft, B.A., Renner, A., Skaret, G., Macaulay, G.J. \& Bergstad, O.A. 2018. Protocols for trawl sampling, recording of biological data, and hydrography for the 2019 International Synoptic Krill Survey in Area 48. CCAMLR, WG-EMM-18/23: 17 pp.

Krafft, B.A., Bergstad, O.A., Knutsen, T., Skaret, G. \& Macauley, G.J. 2018a. Multinational large-scale krill synoptic survey in CCAMLR Area 48 in 2019 - survey plan and protocol for consideration by SG-ASAM 2018. CCAMLR, SG-ASAM-18/07: 8 pp.

Krafft, B.A., Lowther, A., Macaulay, G., Chierici, M., Biuw, M., Renner, A., Klevjer, T.A., Øyerhamn, R., Cárdenas, C.A., Arata, J., Makhado, A., Reiss, C. \& Bergstad, O.A. 2018b. Development of methods relevant to feedback management (FBM) for the krill fishery. CCAMLR, WG-EMM-18/08: 16 pp.

Lillo, S. \& Guzmán, O. 1982. Estudio de la abundancia, distribución y comportamiento del krill en el Estrecho de Bransfield y Paso Drake, mediante técnicas hidroacústicas. INACH, Serie Científica, 28: 23-35.

Loeb, V., Siegel, V., Holm-Hansen, O., Hewitt, R., Fraser, W., Trivelpiece, W. \& Trivelpiece, S. 1997. Effects of sea-ice extent and krill or salp dominance on the Antarctic food web. Nature, 387: 897-900.

Macaulay, G., Skaret, G., Knutsen, T., Bergstad, O.A., Krafft, B., Fielding, S., et al. 2019. Biomass results from the International Synoptic Krill Survey in Area 48, 2019. CCAMLR, SG-ASAM-2019/08: 28 pp.

Meyer, B. 2012. The overwintering of Antarctic krill, Euphausia superba, from an ecophysiological perspective. Polar Biology, 35: 15-37. doi: 10.1007/ s00300-011-1120-0

Meyer, B. 2017. Myths and legends: links to ice, depth distribution, and population trajectories. $3^{\text {erd }}$ International Symposium on Krill, St Andrews, Scotland, 12 to 16 June 2017.

Miller, D. \& Hampton, I. 1989. Biology and ecology of the Antarctic krill (Euphausia superba, Dana): a review. Biomass Scientific Series, 9: 66 pp.

Moffat, C. \& Meredith, M. 2018. Shelf-ocean exchange and hydrography west of the Antarctic Peninsula: a review. Philosophical Transactions of the Royal Society A, 376(2122): 20170164. doi: 10.1098/rsta. 2017.0164

Nicol, S. \& Endo, Y. 1997. Krill fisheries of the world. FAO Fishery Technical Paper, 367: 100 pp.

Nicol, S. \& Endo, Y. 1999. Krill fisheries: development, management, and ecosystem implications. Aquatic Living Resources, 12(2): 105-120. doi: 10.1016/ S0990-7440(99) 80020-5 
Nicol, S., Forster, I. \& Spencer, J. 2000. Products derived from krill. In: Everson, I. (Ed.). Krill, biology, ecology, and fisheries. Fish and Aquatic Resources Series, 6, Blackwell Science, New Jersey, pp. 262-283.

Pakhomov, E.A., Froneman, P.W. \& Perissinotto, R. 2002. Salp/krill interactions in the Southern Ocean: spatial segregation and implications for the carbon flux. Deep Sea Research Part II, 49: 1881-1907. doi: 10.1016/S0967-0645(02)00017-6

Perry, F., Atkinson, A., Sailley, S.F., Tarling, G.A., Hill, S.L., Lucas, C.H. \& Mayor, D.J. 2019. Habitat partitioning in Antarctic krill: spawning hotspots and nursery areas. CCAMLR WG-EMM-2019/20: 64 pp.

Saba, G.K., Fraser, W.R., Saba, V.S., Iannuzzi, R.A., Coleman, K.E., Doney, S.C., Ducklow, H.W., Miles, T.N., Patterson-Fraser, D.L., Stammerjohn, S.E., Steinberg, D.K. \& Schofield, O.M. 2014. Winter and spring control on the summer food web of the coastal west Antarctic Peninsula. Nature Communications, 5: 4318. [http://www.ncbi.nlm.gov/pubmed/25000452]. Reviewed: June 15, 2019.

Siegel, V. 1986. Structure and composition of the Antarctic krill stocks in the Bransfield Strait Antarctic Peninsula during the second International BIOMASS Experiment SIBEX. Archiv für Fischereiwiss, 37: 5172.

Siegel, V. 1992. Review of length-weight relationships for Antarctic krill. CCAMLR, WG-KRILL-92/15: 9 pp.

Siegel, V. \& Loeb, V. 1994. Length and age at maturity of Antarctic krill. Antarctic Science, 6(4): 479-482.

Skjoldal, H.R., Wiebe, P.H., Postel, L., Knutsen, T., Kaartvedt, S. \& Sameoto, D.D. 2013. Intercomparison of zooplankton (net) sampling systems: Results from the ICES/GLOBEC sea-going workshop. Programm of Oceanography, 108: 1-42. doi: 10.1016/j.pocean. 2012.10.006

Received; 23 July 2019; Accepted: 21 January 2020
Trathan, P.N., Everson, I., Miller, D.G.M., Watkins, J.L. \& Murphy, E.J. 1995. Krill biomass in the Atlantic. Nature, 367: 201-202.

Trathan, P.N., Watkins J.L., Murray, A.W.A., Brierley, A.S., Everson, I., Goss, et al. 2001. The CCAMLR2000 Krill Synoptic Survey: a description of the rationale and design. CCAMLR Science, 8: 1-24.

Trathan, P.N., Warwick-Evans, V. \& Young, E. 2019. Considerations about managing the krill fishery at small spatial and temporal scales. CCAMLR, WGEMM-2019/22: 38 pp.

Walsh, J.G. (Ed.). 2014. AMLR2010-2011 field season Report. NOAA-TM-NMFS-SWFSC, 524: 72 pp.

Watters, G.M., Hill, S.L., Hinke, J.T., Matthews, J. \& Reid, K. 2013. Decision-making for ecosystem-based management: evaluating options for a krill fishery with an ecosystem dynamics model. Ecological Applications, 23: 710-725.

Watters, G.M., Hinke, J.T. \& C.S. Reiss. 2016. A feedback management strategy for the krill in Subarea 48.1. CCRVMA, WG-EMM-16/48: 18 pp.

Watkins, J.L. 2000. Aggregation and vertical migration. In: Everson, I. (Ed.). Krill, biology, ecology, and fisheries. Fish and Aquatic Resources Series, 6, Blackwell Science, New Jersey, pp. 80-102.

Watkins, J.L., Hewitt, R.P., Naganobu, M. \& Sushin, V.A. 2004. The CCAMLR 2000 Survey: a multinational, multi-ship biological oceanography survey of the Atlantic sector of Southern Ocean. Deep-Sea Research II, 51: 1205-1213.

Zhu, G., Deng, B., Zhang, H. \& Yang, Q. 2019. Ontogenetic and temporal diet variation in adult Antarctic krill Euphausia superba at South Georgia during austral winter revealed by stable isotope analysis. Fishery Research, 215: 1-8. 